\title{
Modern Monetary Theory: A Wrong Compass for Decision-Making
}

\author{
In the last few years, the so-called Modern Monetary Theory (MMT) has been gaining \\ prominence in the media and the public. This article presents the MMT approach to \\ money and monetary policy, and discusses its recommendations regarding fiscal policy \\ and aggregate demand management, the structural policies it advocates as well as the \\ international aspects of MMT. Overall, it appears that MMT is based on an outdated state of \\ economic science and that its claims regarding economic policies are much exaggerated: \\ The meaning of MMT is more that of a political manifesto than of a genuine economic \\ theory.
}

Georg Friedrich Knapp's (1905) The State Theory of Money (STM) provides the main theoretical underpinning of the Modern Monetary Theory's (MMT) approach to money. We briefly expose STM's link with MMT and then analyse the recommendations of MMT related to money, monetary policy and the role of the central bank. We also consider historical precedents and a possible implementation of MMT in the USA.

\section{An erroneous representation of monetary policy}

The main ideas expressed in STM that are used in MMT can be summarised as follows: Money is a creature of the law; it is a means of payment; it is a token, a representation, hence the reference by Knapp to the Latin word charta that he translates into token and that has given rise to the word "chartalism" to refer to Knapp's and his followers' ideas. Both approaches also hold a narrow vision of money as a means of payment, thus ne-

(C) The Author(s) 2021. Open Access: This article is distributed under the terms of the Creative Commons Attribution 4.0 International License (https://creativecommons.org/licenses/by/4.0/).

Open Access funding provided by ZBW - Leibniz Information Centre for Economics.

Françoise Drumetz, Banque de France; and Sciences Po, Paris, France.

Christian Pfister, Paris 1 Panthéon Sorbonne; and Sciences Po, Paris, France. glecting its other roles as a unit of account and a store of value.

STM and Knapp as well as MMT and MMT economists both present themselves as unorthodox, at odds with "mainstream" economists. Indeed, their attempt to produce a theory has been seriously questioned. For instance, reviewers noted that STM says nothing about the value of money and lacks correspondence with historical facts, while Ocampo (2020) has labelled MMT "Magical Monetary Thinking".

However, one important difference between STM and MMT is that, although this does not seem to be stated in any MMT publication, money is considered in MMT as a pure asset that the state can create at will, whereas STM views money as both an asset and a liability.

Money, monetary policy and the role of the central bank

Regarding money, MMT adopts what Tobin (1963) calls the "fountain pen" approach to money (i.e. the belief that money can be created ad libitum, by the stroke of a pen), applying it to the government - systematically called "the state" - instead of the banks in the Chicago Plan (Pfister, 2020). For instance, Wray $(2014,28)$ writes, "There is no limited supply of either private or state IOUs - so long as either is willing to issue IOUs, they can be supplied" and he derives from this truism that "the limit is on the demand side". According to Wray (2014), what matters

is acceptability on the demand side. As a sovereign power, however, the state can mandate at least some demand for its IOUs by imposing obligations that must 
be paid in the state's currency. Beyond that, by sitting at the apex of the "money pyramid", the state's IOUs are demanded for clearing purposes and also for reserves of the most liquid assets (29).

As Wray (2014) does not define what he means by the "state's IOUs", we identify this notion with the more common one of "monetary base", i.e. the sum of cash in circulation and reserves, defined in the literature as the demand deposits held by monetary policy counterparties (i.e. banks) with the central bank. On that basis, and keeping in mind that banks use reserves to settle their net positions after clearing (with a quasi-null impact on the aggregate demand for reserves), it appears that Wray (2014) confuses something. This confusion, in line with the definition by STM of money as a means of payment, is between legal (or fiat) currency (e.g. the euro or the dollar) and cash (or forced course currency, i.e. currency that has to be accepted in payment and that cannot be exchanged for outside money). Furthermore, the use of cash by economic agents is nowadays limited and reserves are used by banks only as a vehicle to settle transactions, with almost no impact on the aggregate demand for them; instead, economic agents use private money in most of their payments. This confusion is also common to other MMT authors (see e.g. Kelton, 2020, 15-41); however, none of them ever explains why modern literature on money defines what makes legal currency "acceptable" by the public, i.e. monetary policy credibility. Neither do they envisage the possibility of currency competition. Instead, they prefer to insist on the constraints that "the state" puts on the public.

Regarding monetary policy and the role of the central bank, in contrast with standard monetary economics, MMT does not provide an explanation of monetary policy strategy or a description of the monetary transmission mechanism from monetary policy decisions to the broader economy. Instead, it considers that law should set the objectives and the conduct of monetary policy, possibly in the details - e.g. prescribing a given interest rate level - and it focuses on one specific aspect of monetary policy implementation: liquidity management by the central bank, usually regarded as the "nuts and bolts" of monetary policy. Even more specifically, it focuses on the interaction between this management and the operation of the Treasury's account with the central bank, starting from the correct observation that the central bank and the Treasury need to coordinate for the former to be able to manage bank liquidity properly. Indeed, this coordination is useful: Since the central bank keeps the account of the Treasury, any flow into or out of this account impacts banks' liquidity. However, MMT never explains what "coordination" entails, instead let- ting the reader assume that the central bank would receive instructions from the Treasury that dictate the amount of liquidity to be provided or withdrawn. In fact, the central bank receives no more than the Treasury's forecast of the expected changes on its account with the central bank over the forecasting period of the "autonomous factors" (i.e. the period before the next open market operation).

MMT economists also consider the monetisation of public debt that takes place through central banks' asset purchases (quantitative easing) as "business as usual". In that regard, Kelton (2020), apparently considers money as an asset that the government could create ex nihilo, a sort of celestial manna, and gives the example of Japan. There, "half of its [the government's] debt has been retired (i.e., paid off [emphasis added]) by its central bank. And it could easily go all the way to 100 percent. If it did, Japan would become the least indebted country in the world" (Kelton, 2020, 93-94). In fact, Kelton overlooks that reserves created by the central bank to purchase public securities would leave the amount of public liabilities unchanged, which is clear when one consolidates the balance sheets of the government and the central bank. Even if one leaves out this extreme example, it appears that, in MMT's approach to monetary policy, fiscal dominance is the rule.

\section{Historical precedents and possible implementation in the USA}

Both historical precedents and an attempt to measure the impact of the MMT programme in the USA through public debt monetisation provide strong cautionary tales against such an approach.

According to Edwards (2019),

Almost every one of the Latin American experiments with major central bank-financed fiscal expansions took place under populist regimes and all of them ended badly.... In most of these episodes..., policy makers used arguments similar to those made by MMTers to justify extensive use of money creation to finance very large increases in public expenditures (3).

Ocampo (2020) also mentions the case of Argentina under Peron (1946-1955) or Peronist regimes, particularly the years 1946-1948, 1973-1974, 2007, 2012 and 2020, and the one of Nazi Germany between 1937 and 1945.

Palley (2019a) evaluates that the full monetisation by the central bank of the increase in the public deficit caused by the implementation of the MMT programme in the 
USA would imply a fiftyfold increase in the monetary base-to-GDP ratio relative to the 2018 . He highlights that those money supply dynamics "would almost certainly trigger high inflation in both asset markets and goods markets, as well as causing significant inflationary and destabilizing exchange rate depreciation" (Palley, 2019a, 153).

Indeed, already in 1982, Sargent had studied the end of four big inflations (Austria, Hungary, Poland and Germany in the 1920s) showing that

it was not simply the increasing quantity of central bank notes [in modern economies, reserves] that caused the hyperinflation..., it was the growth of fiat currency that was unbacked, or backed only by government bills, which there never was a prospect to retire through taxation (89).

\section{A limitless "fiscal space"}

Lerner's (1943) Functional Finance Theory (FFT) builds on Knapp's STM and on Keynesian theory, and has provided the fundamental building block for MMT's fiscal doctrine. Lerner adds a radical fiscal doctrine, referred to as "functional" because it focuses on the macroeconomic outcome of fiscal policy rather than on its budgetary impact (Wray, 2018). Fiscal policy should be judged only by "the results of [its] actions on the economy and not by any established traditional doctrine about what is sound or unsound" (Lerner, 1943, 39). Lerner (1943) prescribes three principles to achieve full employment and price stability:

- public spending should be increased when aggregate demand is too low and taxes increased when aggregate demand is too high;

- public borrowing should be adjusted "in order to achieve the rate of interest which results in the more desirable level of investment" (41), i.e. the level conducive to full employment;

- the government should "print, hoard or destruct" (41) money as needed to carry out the first two principles.

Lerner sees no reason for assuming that the government must always be borrowing more money and increasing the national debt because the application of functional finance would maintain the proper level of total demand for current output and provide an automatic tendency for the budget to be balanced. Moreover, he sees "no danger for society" of a continually increasing national debt because debt "is not a burden on the nation in the same way as an individual's debt to other individuals is a burden on the individual" (Lerner, 1943, 42-43).

However, Lerner acknowledges that FFT would be invalidated if government debt were foreign held or denominated in foreign currency. The level of debt would then be a constraint because the government would not be able to print money to service the debt. According to Lerner, FFT is only applicable to countries that can borrow long term in their own currency.

\section{Fiscal policy and aggregate demand management}

MMT's fiscal policy doctrine builds on FFT's dismissal of debt constraints on government borrowing (Mitchell, 2020). It also argues that a sovereign currency issuer (i.e. with debts denominated in its own currency and a floating exchange rate) is financially unconstrained, rejects the "orthodox" notion of fiscal sustainability and adopts a very specific conception of "fiscal space". Within this approach, when the economy is at full capacity, the emergence of inflationary risks can be controlled through a tax increase. Tax adjustments serve to control aggregate demand, not to finance the fiscal deficit, because whenever the government spends, money is created (as mentioned above, MMT confuses money with the monetary base, i.e. currency and reserves). Following the same line of reasoning, bond sales are not viewed by MMT as financing operations. As indicated above, bond sales are considered as interest rate management in which the issuance of government debt, weighing on bank liquidity, increases interest rates as if the central bank were not neutralising these effects, precisely in order to make its monetary policy stance prevail.

MMT rejects the orthodox loanable funds theory, deemed irrelevant for understanding the inflationary risk attached to fiscal expansion. The crowding out effect on private spending does not exist in MMT because an expansionary fiscal policy is supposed to lower interest rates by providing liquidity to banks rather than raising them by crowding out the private demand for debt financing. Therefore, interest rates do not reflect the size of the current or expected future levels of deficits and debt as posited by the loanable fund theory (Fullwiler, 2007).

The conclusions drawn by MMT are overstated:

- Even a temporary monetised fiscal stimulus could trigger expectations, especially from the government, that a one-time use could easily become permanent. In turn, a permanent recourse to monetary issuance would lead to a flight from currency and to hyperinflation. 
- MMT's claim that government spending is only constrained by the "inflationary" ceiling, which binds when all productive resources are fully employed (Mitchell, 2020), is incomplete. MMT does not address the opportunity costs and distributional consequences of the monetisation of deficits by the central bank, e.g. its impact on asset prices, that may affect both the demand and the supply side of the economy and therefore the inflation constraint, even before full employment is reached.

- MMT argues that the normal interest rate for government debt should be very low or even zero. This assumption begs the question of the plausibility of interest rates permanently below the growth rate of the economy.

- A government deficit may lead to an increase in longer-term interest rates (Lavoie, 2019; Palley, 2019b) if financial markets expect high future inflation well before full employment has been reached. If the debt is not willingly absorbed by the market, the recourse by the government to financial repression would not prevent interest rates rising in private credit markets with adverse consequences in terms of monetary and financial stability.

- The assumption that a sovereign currency issuer will not default on a debt issued in its currency because the central bank can always print the money needed to service and repay this debt is overstated (Buiter and Mann, 2019; Ocampo, 2020; Palley, 2019b).

MMTers believe that fiscal policy is much more effective than monetary policy at managing aggregate demand. Therefore, fiscal policy should be adjusted when necessary to maintain full employment and moderate inflation while monetary policy should passively support the financing of the fiscal deficit by printing money and keeping interest rates at very low, near-zero levels.

A major criticism that can be addressed to MMT is that its proponents are unable to prove their claims given the lack of formal modelling. In line with this criticism, the following appraisal reviews MMT's key assumptions on inflation, monetary policy, fiscal policy and their (lack of) feedback.

According to Palley (2019b), MMT is especially dismissive of the problem of inflation and lacks a doctrine. For instance, Wray (2019) writes: "Fortunately - or unfortunately depending on one's view - modern economies usually operate with sufficient slack that even large boosts to aggregate demand are not likely to put much pressure on wages and prices. Our critics continue to fight an inflation battle that was won almost two generations ago" (7).

As regards monetary policy's role in managing aggregate demand, MMT's discarding of interest rates as a tool of stabilisation policy is problematic. First, Tymoigne and Wray (2013) posit that the "sensitivity" of aggregate demand to interest rates is low. As interest rates are seen as affecting the cost of borrowing, which influences costs of production and prices, low interest rates may lead to lower inflation; however, such a cost-push argument is purely short term in nature. Second, discarding interest rates as a stabilisation tool would create political economy and instrument shortage problems (Palley, 2019b). From a political economy point of view, monetary policy is the preferred instrument to manage aggregate demand because fiscal policy is difficult to use to stabilise the business cycle. In addition, the loss of an instrument would compound the difficulty for a policymaker to achieve her policy targets. Third, MMT's prescription to keep nominal interest rates at a very low, near-zero level would also foster macroeconomic instability, with, during the upward phase of the cycle, real rates falling and potentially causing higher inflation, which would in turn lower real interest rates.

\section{Structural policies focused on full employment in the USA}

In MMT's view, full employment would be achieved through a government job creation programme, which would act as an automatic stabiliser, and by large-scale spending on infrastructure, climate adaptation and the environment, i.e. the "Green New Deal", which would employ workers in the job creation programme.

\section{The Public Service Employment Programme and the Green New Deal}

MMT believes that a modern capitalist economy, which is inherently instable, will fail to produce and maintain "true" full employment; involuntary unemployment is a persistent characteristic of such economies (Fullwiler, 2007; Tcherneva, 2012; Haim, 2021). Therefore, MMT advocates for the implementation of a US public job creation programme funded by the federal government, called the Public Service Employment (PSE) programme (Wray et al., 2018). The PSE programme is a job guarantee programme

that provides employment to all who need work by drawing from the pool of the otherwise unemployed 
during recessions and shrinking as private sector employment recovers....[T] pay a wage (whose level would be gradually incremented to reach $\$ 15$ per hour in 2022) for full- and part-time positions and offer benefits that include health insurance and childcare. In addition to guaranteeing access to work on projects that serve a public purpose, the PSE programme establishes effective minimum standards for wages and benefits (Wray et al., 2018, 1).

The programme would not aim at competing directly with private sector employment: Jobs created would provide public services in non-profit community organisations, public schools, and state and local governments.

According to MMT economists, the implementation of PSE would bring many benefits (Tcherneva, 2012; Wray et al., 2018; Ehnts and Höfgen, 2019). It would stabilise economic activity and household incomes. The government's budget would also move in a countercyclical manner as spending on the programme would fluctuate with the cycle, which would further help to smooth cyclical fluctuations. Moreover, the PSE programme would provide a price and wage anchor.

The Green New Deal (GND), a resolution introduced by US Congresswoman Ocasio-Cortez and Senator Markey, is a comprehensive programme calling for an economic mobilisation in the USA at a scale not seen since the New Deal era. Its chief aims are to radically decarbonise the US economy with a set of policies combining public investment by 2030 while significantly reducing economic inequality. The goal of creating "millions of good, high-wage jobs and ensure prosperity for all" would be achieved through a job guarantee, a central component of the GND (Galvin and Healy, 2020).

\section{A central role but an uncertain success}

Palley (2019b) notes that the government job creation programme is much more central for MMT than would seem at first glance, because fiscal policy, as envisaged by $\mathrm{MMT}$, would have trouble fine-tuning the economy. Therefore, the PSE would function as a counter-cyclical automatic stabiliser, delivering productive non-inflationary full employment. However, the success of such a programme rests on a number of conditions (Buiter and Mann, 2019) that may not all be met. In particular, the authorities must manage a permanent inventory of productive, meaningful jobs and job openings, ready to be filled at short notice in the public sector. By contrast, public sector employment in activities that add little economic value or maintenance of skills at a guaranteed wage would simply be equivalent to unemployment benefits in disguise. The PSE may have other drawbacks, such as the displacement of private sector production if workers prefer better paid or less intensive PSE jobs. Moreover, the fact that the PSE sets the effective minimum wage floor for the entire economy may have inflationary consequences and cause job losses in other parts of the economy. Finally, the GND and the PSE nevertheless reflect MMT's view that government intervention is more desirable and sustainable than private sector action in responding to climate change.

\section{A US-centric open-economy analysis}

Bonizzi et al. $(2019,47)$ note that "MMT analysis of open economy issues, particularly those faced by developing and emerging countries, is relatively scant." Indeed, most of MMT's analyses rely on a closed economy assumption (Ocampo, 2019). When they do not, they appear as US-centric and closely aligned with long-standing US government official views. For example, Kelton (2019) writes, "America's trade deficits are not optional. Much of the world simply must run trade surpluses with America" (143). MMT views current account deficits as a reflection of foreign demand for financial assets, rather than as the result of domestic consumption and investment exceeding productive capacity. The underlying assumption - that the liabilities associated with current account deficits are denominated in the currency of the deficit nation - does not match the reality of the majority of the international trading and financial systems (Bonizzi et al., 2019), except for the US and a few other major reserve currency issuing economies.

MMT's framework is presented by its exponents as applicable to all sovereign currency issuers. Even developing and emerging countries are urged to adopt its prescriptions, as if external constraints on policy and development, driving them to choose an exchange rate peg or to borrow abroad in a foreign currency, were self-imposed and did not reflect limited macroeconomic policy autonomy. However, Bonizzi et al. (2019) consider that the criteria identified by MMT are insufficient to achieve policy autonomy and that "[a]dvocating deficit monetisation under conditions of sustained current account deficits, exchange rate volatility and potential capital flight is at best misguided and at worst irresponsible" (58). In turn, Epstein (2019) considers that "MMT policy is relevant, at best, to only a few countries: those with significant international currencies" (8). Perhaps as a result of these critical remarks, Kelton (2020) advises developing and emerging economies to sign South-South trade agreements and put in place capital controls to gain "monetary sovereignty" (155). However, such measures are likely to 
Table 1

What MMT deems wrong and right

\begin{tabular}{|c|c|c|}
\hline & Wrong & Right \\
\hline \multicolumn{3}{|l|}{ Explicitly } \\
\hline Government expenditure is financed by... & taxes & issuing currency \\
\hline Public debt sustainability... & can be an issue & cannot be an issue \\
\hline Public bonds are issued... & to finance the public deficit & $\begin{array}{l}\text { to distribute income as part of an interest rate } \\
\text { maintenance strategy }\end{array}$ \\
\hline Access of government to central bank financing... & should be limited & is unlimited \\
\hline Public debt purchased by the central bank... & should be paid off & is paid off \\
\hline Crowding out... & can be an issue & cannot be an issue \\
\hline Monetary policy... & has a role to play to stabilise the economy & has no role to play to stabilise the economy \\
\hline Interest rates... & are a market variable & are set by the government \\
\hline Inflation... & is a monetary policy issue & is a fiscal policy issue \\
\hline Unemployment... & cannot be fully eliminated & can be fully eliminated \\
\hline Conventional structural policies... & are positive & are negative \\
\hline A sovereign economy... & should be competitive & does not have to be competitive \\
\hline Skills... & are important determinants of income & are loosely linked to income \\
\hline Social welfare... & has a cost & has no cost \\
\hline \multicolumn{3}{|l|}{ Implicitly } \\
\hline Currency... & is both an asset and a liability & is an asset "manufactured" ad libitum by the state \\
\hline Currency competition... & exists & does not exist \\
\hline Incentives and expectations... & play an major role in economic dynamics & play a minor role in economic dynamics \\
\hline Competition in the goods and services markets... & exists and is useful & can be ignored \\
\hline Climate change... & $\begin{array}{l}\text { can be addressed primarily by setting a } \\
\text { social price of carbon }\end{array}$ & necessitates primarily public investment \\
\hline
\end{tabular}

Source: Authors' own elaboration.

hamper the building of the "deep capital markets" that she deems necessary - and rightly so - to develop a demand for their currencies (144) and thus gain "monetary sovereignty".

\section{Conclusion}

Table 1 summarises the main contrasts between MMT's approach and mainstream economics.

Such a stark contrast with mainstream economics analysis and recommendations would be understandable if MMT economists engaged in a debate with their colleagues to explain and justify their positions from both a theoretical and empirical point of view. However, their academic publications are repetitive and lacking in empirical analysis, which does not allow for the verification of their assertions or the comparison with the recommendations of other schools of thought. As Hartley
(2020) notes, MMT "is not a falsifiable scientific theory: it is rather a political and moral statement by those who believe in the righteousness - and affordability - of unlimited government spending to achieve progressive ends". Its meaning is more that of a political manifesto than of a genuine economic theory.

\section{References}

Bonizzi, B., A. Kaltenbrunner and J. Michell (2019), Monetary sovereignty is a spectrum: modern monetary theory and developing countries, real-world economics review, 89, 46-61.

Buiter, W. and C. L. Mann (2019), Modern Monetary Theory (MMT): What's right is not new, what's new is not right, and what's left is too simplistic, Citi GPS Insights.

Edwards, S. (2019), Modern Monetary Theory: Cautionary Tales from Latin America, Hoover Institution Economics Working Papers, 19106.

Ehnts, D. H. and M. Höfgen (2019), Modern monetary theory: a European perspective, real-world economics review, 89, 75-84.

Epstein, G. (2019), Is MMT “America First” Economics?, INET blog. 
Fullwiler, S. T. (2007), Interest Rates and Fiscal Sustainability, Journal of Economic Issues, 41(4), 1003-1042.

Galvin, R. and N. Healy (2020), The Green New Deal in the United States: What it is and how to pay for it, Energy Research \& Social Science, 67, 1-9.

Haim, D. (2021), What Jobs Should a Public Job Guarantee Provide? Lessons from Hyman P. Minsky, Levy Economics Institute of Bard College, Working Paper, 981.

Hartley, J. (2020), The Weakness of Modern Monetary Theory, National Affairs, Fall, 70-82.

Kelton, S. (2020), The Deficit Myth: Modern Monetary Theory and How to Build a Better Economy, John Murray.

Knapp, G. F. (1905), The State Theory of Money, abridged and translated by H. M. Lucas and J. Bonar, Macmillan \& Company.

Lavoie, M. (2019), Modern monetary theory and post-Keynesian economics, real-world economics review, 89, 197-108.

Lerner, A. P. (1943), Functional Finance and the Federal Debt, Social Research, 10, 38-51.

Mitchell, W. (2020), Debt and Deficits - an MMT perspective, Centre of Ful Employment and Equity, Working Paper, 20-05.

Ocampo, E. (2020), MMT: Modern Monetary Theory or Magical Monetary Thinking? The Empirical Evidence, Universidad del Cema, Documentos de Trabajo, 762.

Palley, T. I. (2019a), Macroeconomics vs. modern money theory: some unpleasant Keynesian arithmetic and monetary dynamics, real-world economics review, 89, 148-155.
Palley, T. I. (2019b), What's Wrong with Modern Money Theory (MMT): a Critical Primer, Hans-Böckler Stiftung, FMM Working Paper, 44.

Pfister, C. (2020), 100\% Reserve: Calamity or Opportunity?, Banque de France Working Paper, 786.

Sargent, T. J. (1982), The End of Four Big Inflations, in R. E. Hall (ed.), Inflation: Causes and Effects, University of Chicago Press, 41-97.

Tcherneva, P. R. (2012), Beyond Full Employment; The Employer of Last Resort as an Institution for Change, Levy Economics Institute of Bard College, Working Paper, 732.

Tobin, J. (1963), Commercial Banks as Creators of "Money”, Cowles Foundation, Discussion Paper, 159.

Tymoigne, E. and L. R. Wray (2013), Modern Money Theory 101: A Reply to Critics, Levy Economics Institute of Bard College, Working Paper, 778.

Wray, L. R. (2014), From the State Theory of Money to Modern Money Theory: An Alternative to Economic Orthodoxy, Levy Economics Institute of Bard College, Working Paper, 792.

Wray, L. R. (2018), Functional Finance: A Comparison of the Evolution of the Position of Hyman Minsky and Abba Lerner, Levy Economics Institute of Bard College, Working Paper, 900.

Wray, L. R. (2019), Alternative paths to modern money theory, real-world economics review, 89, 5-22.

Wray, L. R., F. Dantas, S. Fullwiler, P. R. Tcherneva and S. A. Kelton (2018), Public Service Employment: A path to full employment, Levy Economics Institute of Bard College, Research Report. 